\title{
Simultaneous stent placement for biliary and afferent loop obstruction due to tumor recurrence after pancreatoduodenectomy
}

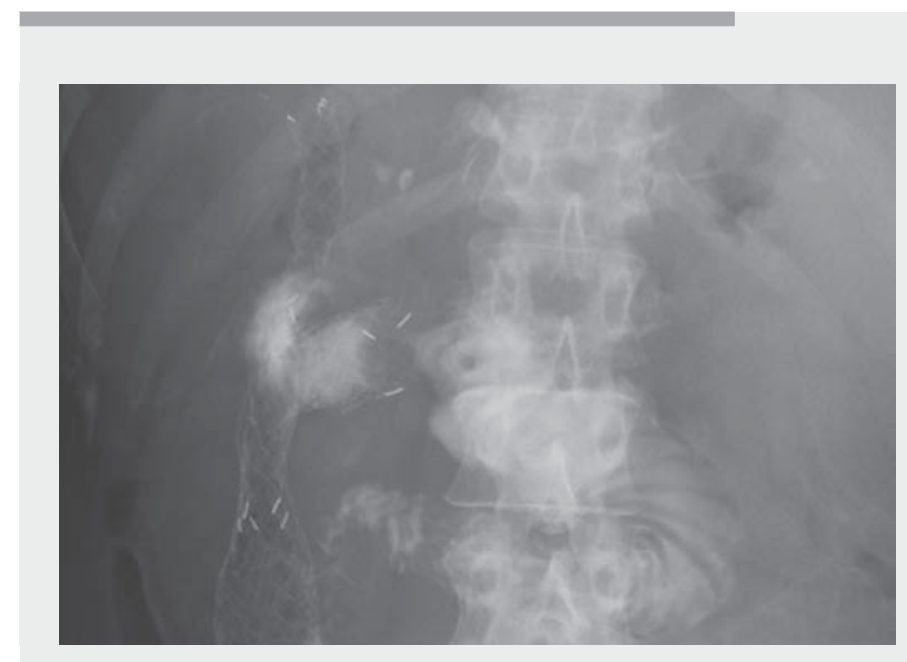

$\nabla$ Video 1 We performed simultaneous endoscopic metallic stent placements using the stent-in-stent technique for afferent loop obstruction with cholangitis and liver abscess due to a recurrent tumor after a pancreatoduodenectomy.

After pancreaticoduodenectomy, patients experiencing tumor recurrence involving the Roux limb can suffer from afferent loop syndrome, cholangitis, and jaundice [1]. Placement of expandable metal stents at the site of enteral obstruction is considered a reasonable treatment option [2-4]. However, when the tumor recurs near the choledochojejunostomy, biliary and enteral stent placements would be required to decompress the dilated bile duct and afferent loop. Herein we report the first case of afferent loop syndrome with cholangitis and liver abscess treated by simultaneous metal stent placement using the stent-in-stent technique.

A 55-year-old woman with a 2-year history of pancreaticoduodenectomy with modified Child reconstruction for pancreatic cancer was admitted to our hospital for the treatment of cholangitis. Contrast-enhanced computed tomography showed the dilatation of the afferent loop and the bile duct due to a recurrent tumor near the choledochojejunostomy and a liver abscess in the right hepatic lobe. A lower gastrointestinal endoscope (PCF-Q260Jl; Olympus, Tokyo, Japan) was inserted into the afferent loop ( Video 1). A guidewire was advanced across the stricture and inserted into the bile duct; contrast injection revealed the stenotic regions of the afferent loop. Another guidewire was placed in the dilated afferent loop ( Fig.1). Subsequently, we proceeded with the placement of two uncovered stents (A: enteral, $22 \mathrm{~mm}$ in diameter, $100 \mathrm{~mm}$ long, Niti-S duodenal; and B: metallic, $10 \mathrm{~mm}$ in diameter, $100 \mathrm{~mm}$ long, Niti-S large cell; Taewoong Medical, Seoul, Korea). Stent A was placed in the afferent loop ( Fig. 2); then, a guidewire was advanced toward the bile duct through the stent mesh of the enteral stent and stent $B$ was placed successfully using the stentin-stent technique ( $\mathbf{F i g} \cdot \mathbf{3}$ ). No complications were observed; the patient's liver abscess and cholangitis improved.

Endoscopy_UCTN_Code_TTT_1AR_2AK

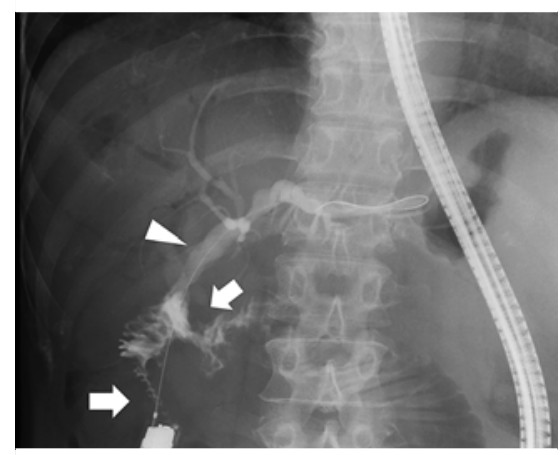

- Fig. 1 Fluoroscopic image reveals the afferent loop stenosis (arrow) and the dilated bile duct (arrowhead).

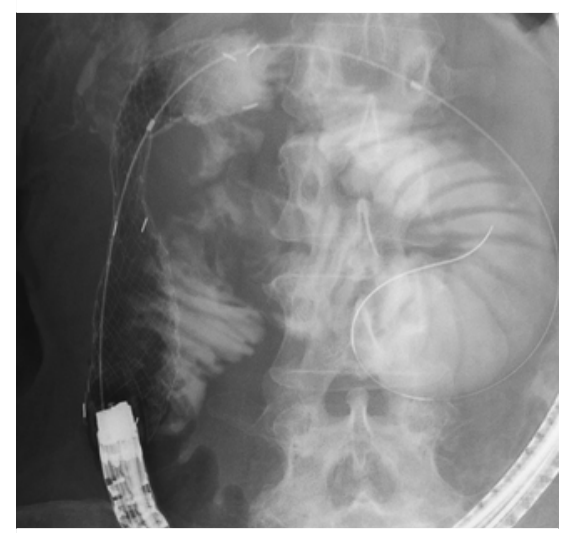

- Fig. 2 An uncovered enteral stent is placed in the afferent loop.

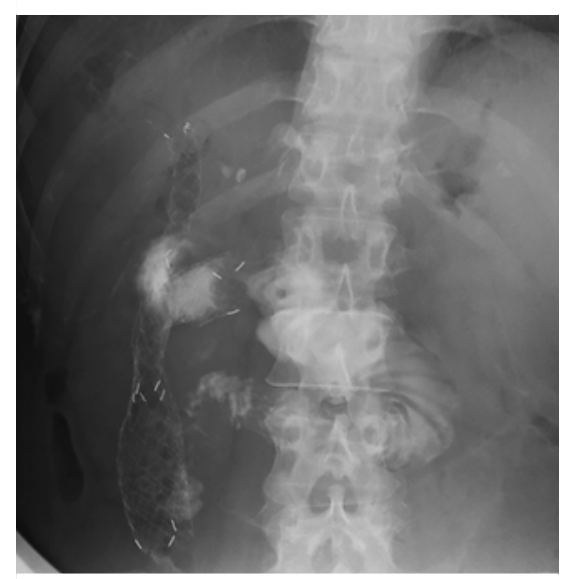

Fig. 3 An uncovered metallic stent is placed in the bile duct using the stent-instent technique. 


\section{Competing interests}

The authors declare that they have no conflict of interest.

The authors

Tatsunori Satoh, Hirotoshi Ishiwatari, Kazuma Ishikawa, Hidenori Kimura, Hiroyuki Matsubayashi, Hiroyuki Ono

Division of Endoscopy, Shizuoka Cancer Center, Shizuoka, Japan

\section{Corresponding author}

\section{Hirotoshi Ishiwatari, MD}

Division of Endoscopy, Shizuoka Cancer Center, 1007 Shimonagakubo Nagaizumicho, Sunto-gun, Shizuoka 411-8777, Japan Fax: +81-55-989-5551

ishihiro481019@gmail.com
[1] Termsinsuk P, Chantarojanasiri T, Pausawasdi N. Diagnosis and treatment of the afferent loop syndrome. Clin J Gastroenterol 2020; 13: 660-668

[2] Sakai A, Shiomi H, lemoto T et al. Endoscopic self-expandable metal stent placement for malignant afferent loop obstruction after pancreaticoduodenectomy: a case series and review. Clin Endosc 2020; 53: 491-496

[3] Kida A, Kido H, Matsuo T et al. Usefulness of endoscopic metal stent placement for malignant afferent loop obstruction. Surg Endosc 2020; 34: 2103-2112

[4] Tanisaka Y, Ryozawa S, Mizuide M et al. Usefulness of self-expandable metal stents for malignant biliary obstruction using a shorttype single-balloon enteroscope in patients with surgically altered anatomy. J Hepatobiliary Pancreat Sci 2021; 28: 272-279
Bibliography

Endoscopy 2022; 54: E524-E525

DOI 10.1055/a-1662-4433

ISSN 0013-726X

published online 25.10.2021

(C) 2021. Thieme. All rights reserved.

Georg Thieme Verlag KG, Rüdigerstraße 14,

70469 Stuttgart, Germany

\section{ENDOSCOPY E-VIDEOS}

https://eref.thieme.de/e-videos

Endoscopy E-Videos is an ind open access online section, 回䡮: reporting on interesting cases and new techniques in gastroenterological endoscopy. All papers include a high quality video and all contributions are freely accessible online. Processing charges apply (currently EUR 375), discounts and wavers acc. to HINARI are available.

This section has its own submission website at

https://mc.manuscriptcentral.com/e-videos 